\section{Red Light Affects Flowering Under Long Days in a Short-day Strawberry Cultivar}

\author{
Fumiomi Takeda ${ }^{1,4}$ and D. Michael Glenn ${ }^{2}$ \\ USDA-ARS, Appalachian Fruit Research Station, 2217 Wiltshire Road, \\ Kearneysville, $W V 25430$
}

Gary W. Stutte ${ }^{3}$

Space Life Sciences Laboratory, Dynamac Corporation, Kennedy Space Center, FL 32899

Additional index words. LED, transplant, propagation, canopy

\begin{abstract}
July-plugged transplants of short-day cv. Strawberry Festival (Fragaria $\times$ ananassa) flowered in October and November although they were grown under long photoperiods and warm temperatures (greater than $21^{\circ} \mathrm{C}$ ) in July and August. These unexpected results were attributed to a high plant density (320 transplants $\left./ \mathrm{m}^{2}\right)$ that provided continuous and heavy leaf cover, which eliminated red light (less than $700 \mathbf{~ n m}$ ) from reaching the crowns. This hypothesis was tested by illuminating crowns of transplants growing in 50-cell packs for $16 \mathrm{~h} \cdot \mathrm{d}^{-1}$ with red light-emitting diode lamps (maximum wavelength at $639 \mathrm{~nm}$ and $80 \%$ of output between 617 and $655 \mathrm{~nm}$ ). Red light treatment caused a significant reduction in fall flowering. It is proposed that a high ratio of far-red light to visible light reaching the crown will play a role in floral bud induction, possibly as early as mid-August. Transplants of some short-day cultivars started as plug plants in early July have the capacity to flower and fruit in the fall and the next spring, enabling growers in the mid-Atlantic coast region to obtain two harvests within 1 year from a single planting.
\end{abstract}

The fall-to-winter strawberry production system in the mid-Atlantic coast region combines the new technologies for containerized nursery (plug) plant production with the protected culture system (Takeda, 1999). Shortday strawberry cultivars such as Carmine (Chandler et al., 2004), Chandler (Voth and Bringhurst, 1984), and Sweet Charlie (Chandler et al., 1997) have been induced to flower in the fall without exposing transplants to cool temperatures or short-day conditions (Takeda and Newell, 2006a, 2006b). Between 73\% and $100 \%$ of 'Carmine' transplants that were propagated in early July and maintained in a greenhouse with high temperatures and a long photoperiod until late August flowered by mid-November when established in the field on 1 Sept. These unexpected results were attributed to a high plant density (320 transplants $/ \mathrm{m}^{2}$ ) that provided a continuous and heavy leaf cover, which eliminated red light (less than $700 \mathrm{~nm}$ ) from reaching the crowns (Takeda, 2008). In contrast, less than $30 \%$ of 'Carmine' transplants rooted in early August flowered in November and December (Takeda and Newell, 2006a). According to Sønsteby and Hytonen (2005), the conditions in which

\footnotetext{
Received for publication 13 May 2008. Accepted for publication 18 June 2008.

${ }^{1}$ Research Horticulturist.

${ }^{2}$ Supervisory Plant Physiologist.

${ }^{3}$ Plant Physiologist.

${ }^{4}$ To whom reprint requests should be addressed; e-mail Fumi.Takeda@ars.usda.gov
}

July-plugged transplants were grown (e.g., long photoperiod and temperatures greater than $21^{\circ} \mathrm{C}$ ) before their establishment in the field are unfavorable for floral bud induction.

Light is a critical environmental factor for reproductive development (Bernier and Périlleux, 2005). Where flower induction is regulated by daylength, the leaves are the primary recipient of the external signal that is transmitted to the meristem where the flowering response occurs (Salisbury and Ross, 1992). Light is absorbed by phytochrome (Phy) and cryptochrome (blue light) photoreceptors, which promote the expression of genes that change the fate of the shoot apical meristem from vegetative growth to reproductive development (Amasino, 1996).

Selective filtering of solar radiation by the plant cover results in greater preponderance of far-red radiation relative to red light (Kasperbauer, 1971). This shift in spectral composition of light is biologically significant in the context of ecological aspects of light on seed germination and vegetative development. Plants grown in dense populations are often taller and lighter in color and have narrower leaves and fewer lateral branches than those grown in sparse populations (Salisbury and Ross, 1992). Changes in light intensity and spectral distribution of light within and below a canopy have been attributed to these growth responses by shaded plants. The effects of red and far-red radiation and natural light in the plant canopy on seed germination have been experimentally established (Mayer and Shain, 1974).
The objective of the present work was to evaluate the effect of red $(600$ to $700 \mathrm{~nm})$ light specifically directed at the crown of transplants on the fall flowering of short-day 'Strawberry Festival' strawberry.

\section{Materials and Methods}

On 1 July 2007, runner tips of 'Strawberry Festival' strawberry were plugged into 50-cell pack trays $\left(\approx 320\right.$ transplants $\left./ \mathrm{m}^{2}\right)$ and misted under intermittent sprinklers for $10 \mathrm{~d}$ to promote rooting. Afterward, all trays were placed on a greenhouse bench and trays were watered and fertilized as needed. In late July, leaves were detached from 10 transplants and leaf area $\left(\mathrm{cm}^{2} /\right.$ plant $)$ was determined with a LI-COR leaf area meter (LI-COR Biosciences, Lincoln, NE). A red light-emitting diode (LED) lamp (Holiday Creations, Inc., Littleton, $\mathrm{CO}$ ) was placed under the leaf canopy $\approx 1 \mathrm{~cm}$ from the crown of each of 100 transplants in two trays (Fig. 1). Individual LED lamps were characterized for spectral distribution and output using a LI-COR 1800 spectroradiometer (LI-COR Biosciences) with a cosine-corrected receptor. The individual lamps were placed in a custom fixture lined with white Teflon paint and positioned $1.5 \mathrm{~cm}$ from the detector head. The individual lamps had a maximum wavelength at 639 $\mathrm{nm}$, a bandwidth of 601 to $672 \mathrm{~nm}$, a total (red 600 to $700 \mathrm{~nm}$ ) output of $3.5 \mu \mathrm{mol} \cdot \mathrm{m}^{-2} \cdot \mathrm{s}^{-1}$ of photosynthetic active radiation $(P A R)$ per lamp, with $80 \%$ of the output in a $30-\mathrm{nm}$ band between 617 and $655 \mathrm{~nm}$ (Fig. 2). The thermal effects on the crown were assumed to be minimal because the total power output of the 70-lamp strand was $2.81 \mathrm{~W}$, and its spectral efficiency was $24 \%$ (OL 770 Vis/ NIR spectroradiometer and OL ISS $39001-\mathrm{m}$ diameter integrating sphere; Optronics Laboratory, Orlando, FL). That is equivalent to less than $1.5 \mathrm{~W}$ being added to each tray of 50 transplants.

From 1 Aug. to 27 Aug., two trays of 'Strawberry Festival' transplants with red light LED lamps and another two trays not receiving the red light treatment were placed in an EGC M-36 growth chamber (Environmental Growth Chambers, Chagrin Falls, $\mathrm{OH})$ under a 16-h light/8-h dark photoperiod with $600 \mu \mathrm{mol} \cdot \mathrm{m}^{-2} \cdot \mathrm{s}^{-1}$ PAR using T8 triphosphor fluorescent lamps (Sylvania FP541/841/ HO; Osram; Sylvania, Westfield, IN) at a constant $24{ }^{\circ} \mathrm{C}$ and $65 \%$ relative humidity. A partition was placed between the two groups of trays. The trays received $1-1.5 \mathrm{~cm}$ of irrigation solution, which was replenished daily with either deionized water or nutrient solution. Average nitrogen application/tray was 49 to $140 \mathrm{mg} \mathrm{NO} / \mathrm{d}$. During the $27-\mathrm{d}$ period in the growth chamber, red light LED lamps were turned "ON" during the 16-h light period.

In mid-August, a UniSpec-DC spectrometer (PP Systems, Amesbury, MA) measured incident and leaf/canopy reflected light above the canopy and at crown level of transplants maintained in 50-cell pack trays to measure intercepted light and transmitted light to the 


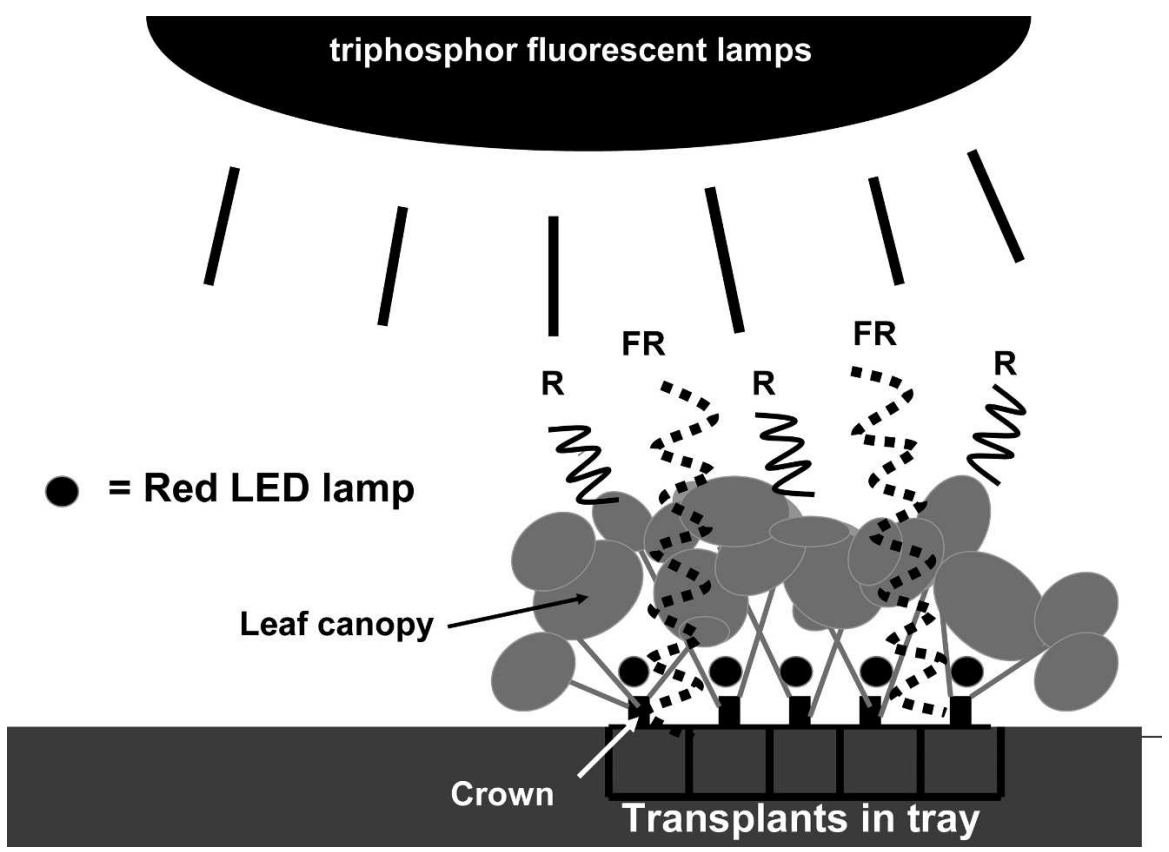

Fig. 1. Schematic representation of red light-emitting diode (LED) treatment in the growth chamber. Transplants were placed under triphosphor fluorescent lamps producing a full spectrum of light from ultraviolet to far-red wavelength. The violet, blue, green, and red (R) wavelength light was absorbed through photosynthesis or reflected by the leaf canopy. Far-red (FR) light passed through the leaf canopy to the crowns. LED lamps (O) placed over the crowns provided supplemental red light.

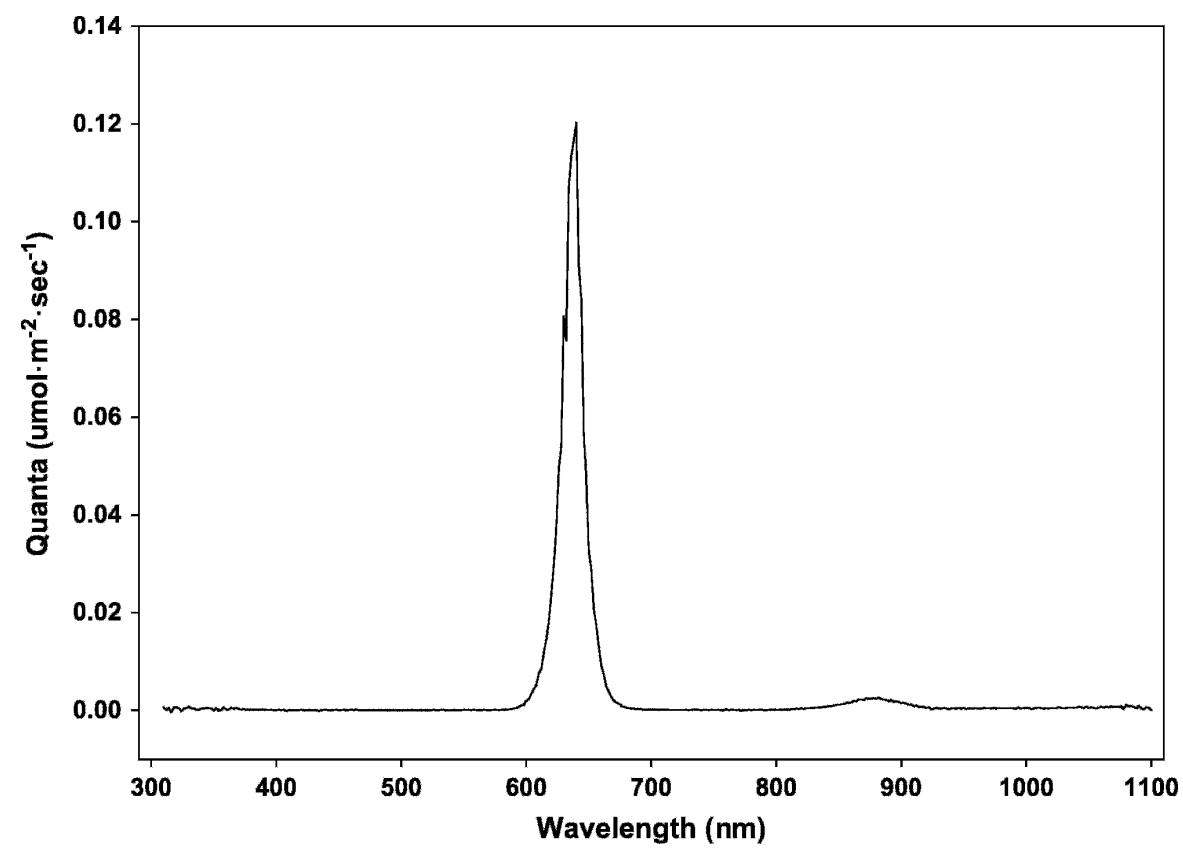

Fig. 2. Spectral output of 70 red light-emitting diode (LED) lamps (Holiday Creations, Inc., Littleton, CO) from 300 to $1100 \mathrm{~nm}$ obtained in a 1-m integrating sphere (Optronics Laboratory, Orlando, FL). Note that the red LED lamps produced maximum output at $639 \mathrm{~nm}$ with bandwidth of 601 to $672 \mathrm{~nm}$ and $80 \%$ of output in a 30-nm band between 617 and $655 \mathrm{~nm}$. The total photosynthetic output was $3.5 \mu \mathrm{mol} \cdot \mathrm{m}^{-2} \cdot \mathrm{s}^{-1}$ per lamp.

crown. A fiberoptic probe was placed just above the leaf canopy and next to a transplant in the middle of a 50-cell pack tray at crown level.

On 29 Aug., all transplants were established $27.5 \mathrm{~cm}$ apart in grow bags (CropKing, Inc., Seville, $\mathrm{OH}$ ) with soilless media atop raised beds inside a high tunnel (Ledgewood Farm Greenhouse Frame, Moultonborough, design with six four-plant replications. The raw flowering percentage data were transformed using the arcsine square root transformation before statistical analysis. The transformed flowering data were subjected to an analysis of variance using Proc GLIMMIX, which uses generalized linear models with a link function to model the binary response in which an individual plant either flowered or not at a given time period (SAS Institute, Cary, NC). This approach allowed modeling the repeated measures aspects of the study.

\section{Results and Discussion}

There was a significant effect of the red LED light treatment on fall flowering in 'Strawberry Festival' plants, but treatment did not interact with sample time. The results suggest that red light from LED lamps directed at the crown delayed flower bud induction in 'Strawberry Festival' strawberry. Flower bud emergence was observed in only $17 \%$ of plants compared with $38 \%$ of control (unlit) plants on 19 Sept. (data not presented). For each sampling time in October, November, and December, individual tests of the odds ratios showed evidence of significantly smaller flowering percentages for the plants exposed to red light in August than for the control plants (Table 1). By late November, $95 \%$ of control plants had open flowers compared with only $54 \%$ of those illuminated with red LED light.

In previous studies, 'Carmine' and 'Chandler' plants initiated flower buds under conditions not favorable for flower bud initiation (Takeda and Newell, 2006b). July-plugged transplants, grown in a greenhouse at high plant density, under long days, and at temperatures greater than $21^{\circ} \mathrm{C}$ during day and night until late August flowered in the fall. It is likely that immature leaves in the bud or tissues that have just emerged from the crown can also perceive light cues to evoke the shoot apical meristem (SAM) to become reproductive (Kerstetter and Hake, 1997). By late July, the transplants possessed a total leaf area of $\approx 300 \mathrm{~cm}^{2} /$ plant and spectroradiometric measurements in mid-August showed no transmission of red light and shorter wavelength light through the leaves, but only farred and near-infrared (IR) light (Fig. 3).

Sunlight reaching the crowns was depleted of wavelength less than $700 \mathrm{~nm}$,

Table 1. Effect of illuminating the crowns of 'Strawberry Festival' transplant with red light-emitting diode lamps for $16 \mathrm{~h} \cdot \mathrm{d}^{-1}$ from 1 to 27 Aug. on flowering in October, November, and December. ${ }^{2}$

$\mathrm{NH})$ at the University of Maryland Wye Research and Education Center in Queensland, MD. A plot consisted of four transplants randomly taken from trays that received red light LED treatment and from trays without red light LED treatment (control). Counts of plants with open flowers were made in Oct., Nov., and Dec. 2007. The experiment was a randomized complete block experimental

\begin{tabular}{lllll}
\hline & \multicolumn{4}{c}{ Flowered plants (\%) } \\
\cline { 2 - 5 } Treatment & 3 Oct. & 24 Oct. & 27 Nov. & 17 Dec. \\
\hline Control & 70.3 & 83.0 & 95.7 & 95.7 \\
Red light & $37.3^{*}$ & $45.7^{*}$ & $58.3^{*}$ & $62.3^{*}$ \\
\hline
\end{tabular}

${ }^{z}$ Transplants were established inside a high tunnel in grow bags on 29 Aug.

${ }^{*}$ The value was significantly smaller than for control plants $(P \leq 0.01)$. 


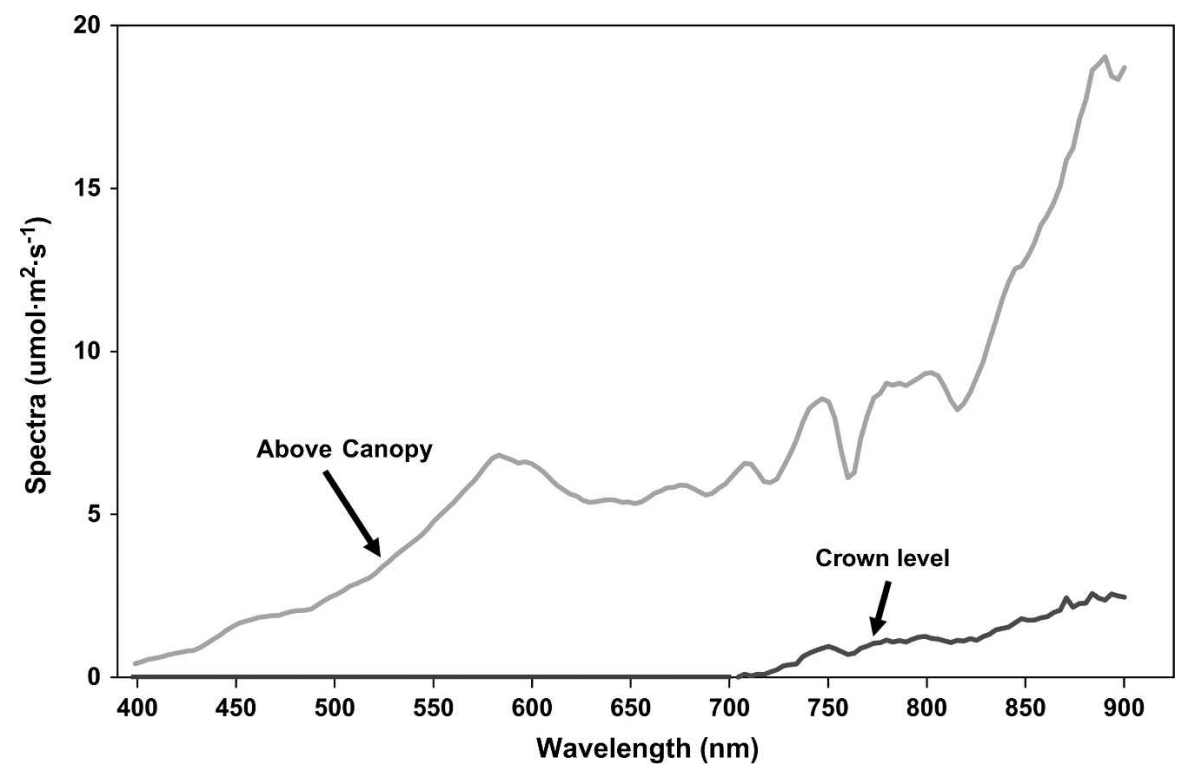

Fig. 3. Intercepted light measured above the leaf canopy and transmitted light at the crowns of 6-week-old strawberry transplants in mid-August with a UniSpec-DC Spectral Analysis System (PP Systems, Amesbury, MA). Spectral response was processed at 2-nm increments. Note that light reaching the crowns was depleted in wavelengths less than $700 \mathrm{~nm}$ because of absorption by the canopy.

most likely as a result of chlorophyll absorbance of $P A R$ and reflectance by the overlaying canopy. Only the far-red and near-IR light passed through to the crowns. It is possible in a natural setting, transition to flowering in the SAM can be affected by a strongly shaded condition. With a full leaf canopy over the crown, more $\mathrm{P}_{\mathrm{r}}$ than $\mathrm{P}_{\mathrm{fr}}$ may be present. A high $\mathrm{P}_{\mathrm{r}}: \mathrm{P}_{\text {fr }}$ ratio would favor activating a signaling pathway that leads to changes in downstream regulation of gene expression and flower bud formation (Amasino, 1996). In contrast, plants growing with wider spacing or plants with lower leaf area will allow sunlight (more red light) to illuminate the crown directly. It is possible that light could reflect off the ground between the plants that would shift Phy to the $\mathrm{P}_{\mathrm{fr}}$ form, thus maintaining the SAM in the vegetative state.

In the present study, a red (600 to $702 \mathrm{~nm}$ ) LED lamp, which provided a total fluence of $3.5 \mu \mathrm{mol} \cdot \mathrm{m}^{-2} \cdot \mathrm{s}^{-1} P A R$ at a distance of $1 \mathrm{~cm}$, was placed under the canopy and $1 \mathrm{~cm}$ directly above the crown of each transplant in a 50-cell pack tray. With this lighting configuration, the Phy response was saturated with only a 38-s exposure (Smith and Whitelam, 1990). Individual LED lamps provided less than $5 \%$ of $P A R$ from lamps above the canopy. It is unlikely that such a small increase in PAR from the red LED lamps would significantly increase photosynthetic rate.

The primary strawberry harvest season in the mid-Atlantic coast region of the United States (lat. $39^{\circ} \mathrm{N}$, long. $77^{\circ} \mathrm{W}$ ) is from early May to late June. However, interest in out-

of-season strawberry production systems is increasing because strawberries harvested in November and December can be directmarketed at $\$ 8.80$ to $\$ 11.00 / \mathrm{kg}$ to restaurants in the metropolitan Washington-Baltimore area (Takeda, personal observation). Making transplants from runner tips harvested in early July and maintaining them through late August at high plant density is a novel method for inducing bloom in the fall in short-day cultivars such as Carmine, Chandler, and Strawberry Festival. Our method differs from forcing techniques that require transplants to be exposed to 14 to 20 daily cycles of 9-h light and chilling temperatures at night (Durner, 1999; Mochizuki et al., 2007; Oda, 1989). The economic feasibility and reliability of the procedure described in this report need to be compared with previously reported techniques of conditioning strawberry transplants. In the mid-Atlantic coast region, Julyplugged transplants conditioned to bloom as early as 1 Oct. in a production system with plasticulture and high tunnel for environmental modifications would allow fruit production from October to late December and continue into the next spring. This will enable growers to obtain two strawberry harvests within 1 year from a single planting.

Although the foregoing work with red light was done with short-day 'Strawberry Festival' strawberry, we have ample evidence to show that fall flowering is inducible in three other short-day cultivars (Takeda, 2008; Takeda and Newell, 2006a). The shift in red light relative to far-red light within a canopy of strawberry transplants appears to play a role in controlling flower bud induction. More studies are needed to fully understand the significance of shade-imposed mechanism for initiating reproductive development in short-day strawberries.

\section{Literature Cited}

Amasino, R.M. 1996. Control of flowering time in plants. Curr. Opin. Genet. Dev. 6:480-487.

Bernier, G. and C. Périlleux. 2005. A physiological overview of the genetics of flowering time control. Plant Biotechnol. J. 3:3-16.

Chandler, C.K., E.E. Albregts, C.M. Howard, and J.K. Brecht. 1997. 'Sweet Charlie' strawberry. HortScience 32:1132-1133.

Chandler, C.K., D.E. Legard, T.E. Crocker, and C.A. Sims. 2004. 'Carmine' strawberry. HortScience 39:1496-1497.

Durner, E.F. 1999. Winter greenhouse strawberry production using conditioned plug plants. HortScience 34:615-616.

Kasperbauer, M.E. 1971. Spectral distribution of light in a tobacco canopy and effects of end of day light quality on growth and development. Plant Physiol. 47:775-778.

Kerstetter, R.A. and S. Hake. 1997. Shoot meristem formation in vegetative development. Plant Cell 9:1001-1010.

Mayer, A.M. and Y. Shain. 1974. Control of seed germination. Annu. Rev. Plant Physiol. 25: 167-193.
Mochizuki, T., M. Okimura, H. Takahashi, Y. Yoshida, N. Sugiyama, and A. Yamasaki. 2007. Recent trends on strawberry cultivars and production technology in Japan. Acta Hort. 761:107-113.

Oda, Y. 1989. Japanese strawberry industryTrend of acreage, production, import and growing systems. Acta Hort. 265:671-678.

Salisbury, F.B. and C. Ross. 1992. Plant physiology. 4th Ed. Wadsworth, Belmont, CA.

Smith, H. and G.C. Whitelam. 1990. Phytochrome, a family of photoreceptors with multiple physiological roles. Plant Cell Environ. 13:695707.

Sønsteby, A. and T. Hytonen. 2005. Manipulating flower induction through temperature and photoperiod fluctuations. Intl. J. Fruit Sci. 5:17-28.

Takeda, F. 1999. Out-of-season greenhouse strawberry production in soilless substrates. Adv. Strawberry Res. 18:4-15.

Takeda, F. 2008. Recent innovations in cultural practices in the mid-Atlantic coast region of the United States: Novel system for increasing fall fruiting in short-day type strawberry cultivars and out-of-season fruit production, p. 32-37. In: Takeda, F., D.T. Handley, and E.B. Poling (eds.). Proc. 2007 N. American Strawberry Symposium. North American Strawberry Growers Association, Kemptville, Ontario, Canada.

Takeda, F. and M. Newell. 2006a. A method for increasing fall flowering in short-day 'Carmine' strawberry. HortScience 39:480-481.

Takeda, F. and M. Newell. 2006b. Effects of runner tip size and plugging date on fall flowering in short-day strawberry (Fragaria xananassa Duch.) cultivars. Intl. J. Fruit Sci. 6:103-117.

Voth, V. and R.S. Bringhurst. 1984. 'Chandler'. U.S. Plant Patent 5262, 24 July. 